\title{
Induction of the Insulin Proreceptor by Hydrocortisone in Cultured Lymphocytes (IM-9 Line)
}

\author{
Dominique G. Rouiller, Aidan McElduff, José A. Hedo, and Phillip Gorden \\ Diabetes Branch, National Institute of Arthritis, Diabetes, Digestive and Kidney Diseases, \\ National Institutes of Health, Bethesda, Maryland 20205
}

\begin{abstract}
Hydrocortisone increases the number of insulin receptors at the surface of human cultured lymphocytes (IM-9 line) without altering the degradation of the mature receptor subunits. To elucidate the effect of glucocorticoids on the biosynthesis of the insulin receptor of IM-9 cells, we preincubated cells in the presence or absence of hydrocortisone $\left(1.4 \times 10^{-6} \mathrm{M}\right)$ and measured the incorporation of radiolabeled sugars into the insulin receptor components.

From 6 to $22 \mathrm{~h}$, there was a progressive increase in the incorporation of $\left[{ }^{3} \mathbf{H}\right]$ mannose into the insulin proreceptor $(190,000 \mathrm{~mol} w \mathrm{w})$ and the mature subunits $(210,000,135,000$, and $95,000 \mathrm{~mol} \mathrm{wt})$. The amount incorporated into hydrocortisone-treated cells was always three to four times higher than in control cells, despite no change in cell number, viability, or radioactive sugar pool. To test directly the earliest effect of hydrocortisone, we undertook pulse-chase studies. The incorporation of $\left[{ }^{3} \mathbf{H}\right]$ mannose into the insulin receptor precursor and the mature subunits was detectable as early as $\mathbf{3 0} \mathrm{min}$ of chase and was two to three times higher in hydrocortisonetreated cells at any time point of incubation. In both groups, the increase into the proreceptor $(190,000 \mathrm{~mol} w t)$ peaked by $60 \mathrm{~min}$ and decreased rapidly thereafter (half disappearance rate, $45 \mathrm{~min}$ ); there was a sustained increase of incorporation into the two major mature subunits $(135,000$ and $95,000 \mathrm{~mol}$ wt) throughout the 4-h chase. Hydrocortisone represents the first pharmacologic agent shown to induce the synthesis of the insulin proreceptor. Further, we present a model system designed to study other agents that may act at a very early step in insulin receptor biosynthesis.
\end{abstract}

\section{Introduction}

The insulin receptor is a critical point at which cellular responsiveness to insulin is determined. While the process of "down" regulation of insulin receptors has been studied in detail (1), there is little information on mechanisms to augment receptor concentration. It has been shown that corticosteroids will increase the concentration of insulin receptors on IM-9

Dr. Rouiller received a fellowship from the Swiss National Science Foundation. Dr. McElduff received a C. J. Martin Fellowship from the National Health and Medical Research Council of Australia.

Address reprint requests to Dr. Rouiller, Diabetes Branch, NIADDK, Building 10, Room 8S-243, National Institutes of Health, Bethesda, MD 20205.

Received for publication 13 February 1985.

J. Clin. Invest.

(c) The American Society for Clinical Investigation, Inc. $0021-9738 / 85 / 08 / 0645 / 05 \quad \$ 1.00$

Volume 76, August 1985, 645-649 cultured human lymphocytes (2). The process is presumably mediated through the corticosteroid receptor (3) and is timeand dose-dependent (4). Further, it has been shown that when cell surface receptors were labeled, their disappearance rate was not decreased by corticosteroids. This led to the conclusion that corticosteroids increase receptor synthesis (4).

Recently, it has been shown that the insulin receptor is synthesized by way of a single chain precursor $(5,6)$. This proreceptor is then proteolytically cleaved and undergoes further posttranslational processing before insertion of the mature subunits into the plasma membrane. Our present studies take advantage of the fact that the insulin receptor is a glycoprotein and that the incorporation of radioactive sugars can be used to study the earliest events in the biosynthesis of the receptor $(6,7)$. The results show that hydrocortisone augments the synthesis of the receptor precursor or proreceptor, providing direct evidence that in IM-9 cultured human lymphocytes corticosteroids increase the concentration of insulin receptors by inducing receptor synthesis.

\section{Methods}

\section{Cell culture and hydrocortisone treatment}

Cultured human IM-9 lymphocytes $\left(1.5-2 \times 10^{6}\right.$ cells $\left./ \mathrm{ml}\right)$ were grown in RPMI 1640 medium (Biofluids, Rockville, MD) containing $25 \mathrm{mM}$ Hepes (Sigma Chemical Co., St. Louis, MO). On the day of the experiment, cells were resuspended at $2.5 \times 10^{6} \mathrm{cells} / \mathrm{ml}$ in fresh medium containing $5 \mathrm{mM}$ glucose and $1.4 \times 10^{-6} \mathrm{M}(0.5 \mu \mathrm{g} / \mathrm{ml})$ hydrocortisone (Sigma Chemical Co.) dissolved in alcohol. The control cells received an identical volume of the $35 \%$ ethanol carrier. The final concentration of ethanol was $<0.01 \%$.

\section{Cell labeling}

Steady-state labeling. At the end of a 6-h preincubation period at $37^{\circ} \mathrm{C}$ in the presence or absence of hydrocortisone, $100 \mu \mathrm{Ci} / \mathrm{ml}$ of $\mathrm{D}$ [2- $\left.{ }^{3} \mathrm{H}(\mathrm{N})\right]$ mannose (specific activity, $27 \mathrm{Ci} / \mathrm{mmol}$ [New England Nuclear, Boston, MA]) was added to the cell culture and the incubation was continued at $37^{\circ} \mathrm{C}$ for variable time periods.

Pulse-chase labeling. These experiments were carried out as previously described by Hedo et al. (6). Briefly, at the end of the preincubation period, the cells were washed twice with phosphate-buffered saline (PBS), incubated $30 \mathrm{~min}$ in glucose-free medium, and concentrated 10 -fold to $2.5 \times 10^{7}$ cells $/ \mathrm{ml} ; 0.5 \mathrm{mCi} / \mathrm{ml}$ of either $\mathrm{D}-\left[2{ }^{3} \mathrm{H}(\mathrm{N})\right]$ mannose or $\mathrm{D}-\left[1,6-{ }^{3} \mathrm{H}(\mathrm{N})\right]$ glucosamine hydrochloride (specific activity, 47 $\mathrm{Ci} / \mathrm{mmol}$ [New England Nuclear]) was then added. After a 15-min incubation at $37^{\circ} \mathrm{C}$ (the pulse), the cells were quickly washed three times with PBS, resuspended at $2 \times 10^{6}$ cells $/ \mathrm{ml}$ in complete medium containing $2 \mathrm{mM}$ of either mannose or glucosamine-hydrochloride, and incubated at $37^{\circ} \mathrm{C}$ for the stated periods of time (the chase). Until the end of the chase, all the washing buffers and the culture media contained either $1.4 \times 10^{-6} \mathrm{M}$ hydrocortisone or the carrier alone (control).

\section{Cell solubilization}

At the end of the biosynthetic incubation period, the cells were counted using a Levy-Hausser Chamber. Their viability, estimated by trypan 
blue exclusion, was always $>95 \%$. They were washed three times with cold PBS, collected by centrifugation, and solubilized in a $\mathrm{NaCl}(150$ $\mathrm{mM})$ Hepes (50 mM) buffer, pH 7.6, containing $1 \%$ Triton X-100, $2 \mathrm{mM}$ phenylmethylsulfonyl fluoride (Sigma Chemical Co.), and 50 mg\% $\alpha$-2-macroglobulin (Boehringer-Mannheim Biochemicals, Indianapolis, IN), for $30 \mathrm{~min}$ on ice with continuous stirring. The mixture was clarified by ultracentrifugation $\left(200,000 \mathrm{~g}, 4^{\circ} \mathrm{C}\right.$ for $\left.1 \mathrm{~h}\right)$. Aliquots $(10 \mu \mathrm{l})$ were taken both before ultracentrifugation and from the soluble extracts for the measurement of total and trichloroacetic acid (TCA)precipitable radioactivity within the samples.

\section{Immunoprecipitation and electrophoresis}

The solubilized insulin-receptors were immunoprecipitated as previously described $(7,8)$ : the ultracentrifugation supernatant was incubated overnight at $4^{\circ} \mathrm{C}$ with either anti-receptor anti-serum "Bd" (titer 1:100), or normal patient serum (titer 1:40). These concentrations of serum were used to obtain approximately the same amount of Coomassie Blue stainable IgG bands on the gels. The immune complexes were adsorbed with Pansorbin (Calbiochem-Behring Corp., La Jolla, CA),

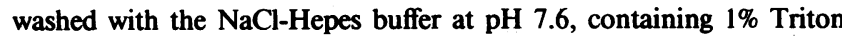
$\mathrm{X}-100$ and $0.1 \%$ SDS, dissociated by boiling for $5 \mathrm{~min}$ in $2 \%$ sodium dodecyl sulfate (SDS), $0.1 \mathrm{M}$ dithiothreitol, $0.5 \mathrm{M}$ mercaptoethanol, $0.002 \%$ bromophenol blue, and $10 \mathrm{mM}$ phosphate buffer, at pH 7 , and recovered in the supernatant after centrifugation at $15,000 \mathrm{~g}$ for $5 \mathrm{~min}$ and recovered in the supernatant after centrifugation at 15,000 $g$ for $5 \mathrm{~min}$. The samples were kept frozen at $-70^{\circ} \mathrm{C}$ until electrophoresis (maximum 1-2 d).

Electrophoresis was performed by a modification of Laemmli (9), using $7.5 \%$ polyacrylamide and $0.1 \%$ SDS slab gels as previously described $(7,8)$. Immunoprecipitates from $2.5 \times 10^{8}$ cells were used for applications to each lane of the gel. Before being dried, the gels were treated with "Enlightning," an autoradiographic enhancer (New England Nuclear). The dried gels were autoradiographed on Kodak XOmat AR film (Eastman Kodak Co., Rochester, NY) at $-70^{\circ} \mathrm{C}$ for $\sim 3$ wk. Quantitative estimates of the radioactivity in the bands of interest were obtained by eluting the sliced bands overnight in $3 \%$ protosol in Econofluor (New England Nuclear) at $37^{\circ} \mathrm{C}$; the radioactivity was then counted in a scintillation counter.

\section{Results}

Steady-state labeling of the insulin receptors. Since, by using both equilibrium binding analysis and immunoprecipitation of surface-labeled receptors, it has been shown that hydrocortisone increases the number of cell surface receptors for insulin on IM-9 cultured human lymphocytes, in order to pursue our inquiry we first determined the effect of the corticosteroid on the level of biosynthetically labeled receptors. After a 6-h preincubation with or without $1.4 \times 10^{-6} \mathrm{M}$ hydrocortisone, IM-9 cells were incubated with $\left[{ }^{3} \mathrm{H}\right]$ mannose in the presence or absence of hydrocortisone for variable periods of time. At selected times thereafter, cells were harvested and solubilized. The soluble material was immunoprecipitated with antireceptor or control serum and the immunoprecipitate applied to a polyacrylamide gel for electrophoresis. There was a latency of $\sim 6 \mathrm{~h}$ before radioactivity was detected in the four previously described insulin receptor components, i.e., with apparent molecular weights of $210,000,190,000,135,000$, and 95,000 (Fig. 1). Radioactivity increased in these bands from 6 to 22 $\mathrm{h}$ and then declined. In hydrocortisone-treated cells, however, the insulin proreceptor $(190,000 \mathrm{~mol} \mathrm{wt})$ and the mature subunits were always more heavily labeled than in the untreated cells.

Pulse-chase studies. To investigate whether the hydrocortisone-induced increase in insulin receptors was due to stimulation of synthesis or receptor stabilization, we studied the earliest events in insulin receptor biosynthesis, using pulsechase techniques. Again, cells were preincubated for $6 \mathrm{~h}$ in the presence or absence of hydrocortisone. To allow early detection of insulin receptor subunits, the radiolabel and the cells were highly concentrated for a short pulse $(15 \mathrm{~min})$, then quickly washed and resuspended at regular concentrations for the chase in the presence of an excess of nonradioactivie label.

In control cells, after $30 \mathrm{~min}$ of chase, the 190,000-mol-wt high mannose precursor of the insulin receptor was the most intensively labeled component (Fig. 2 and Fig. 3, top). As previously shown (6), the incorporation into this band was further increased at $60 \mathrm{~min}$ and decreased thereafter.

In hydrocortisone-treated cells, at any time point the labeling of all components was greater than in the control (258\% at $30 \mathrm{~min}, 283 \%$ at $60 \mathrm{~min}$ ). The disappearance rate, estimated by extrapolation of Fig. 3, was not different from control (half-life $=45 \mathrm{~min}$ ).

The processing of the 190,000 -mol-wt proreceptor to the mature subunits is reflected by the gradual increase in labeling of the 135,000- and 95,000-mol-wt subunits throughout the chase (Fig. 2, and Fig. 3, bottom). Again, at all time points the incorporation was greater in hydrocortisone-treated cells than in control $(261 \pm 48 \%$ for the 135,000 -mol-wt subunit, $229 \pm 44 \%$ for the 95,000-mol-wt subunit; mean increase $\pm 1 \mathrm{SD}$ ).

Results that were similar but somewhat less distinct were obtained at $\mathbf{3 0} \mathrm{min}$ when glucosamine was used as the labeled sugar (data not shown).

Effect of hydrocortisone on cell growth and mannose incorporation. Though it has been reported that glucocorticoids do not alter the growth pattern of IM-9 cells (10), we wished to verify this under our experimental conditions. The presence of hydrocortisone did not significantly affect cell growth (cell number $\times 10^{-6} / \mathrm{ml}=2.76 \pm 1.05$ for hydrocortisone-treated cells and $2.83 \pm 0.86$ for control, mean $\pm 1 \mathrm{SD} ; P=\mathrm{NS}$ ).

Further, we wished to verify that the uptake of $\left[{ }^{3} \mathrm{H}\right]$ mannose was not altered by hydrocortisone, which could alter the initial pool size of the labeled material. We found that the amount of radioactivity incorporated into either the whole cells or the soluble extracts was similar in the presence or absence of hydrocortisone (Table I). Thus, within the sensitivity of the methodology used we were unable to detect a change in the mannose pool size.

\section{Discussion}

Our data show that hydrocortisone increased the incorporation of radioactive mannose into the insulin receptor precursor and mature subunits in IM-9 cultured human lymphocytes. This effect was not due to stimulation of cell division. Further, we have shown that other technical alterations, such as a change in the cellular pool of radioactive sugars, is unlikely, since total intracellular radioactivity was not different in the control and corticosteroid-treated cells. We used radioactive sugar labels because, for technical reasons, they provide the most distinct labeling. Tritiated amino acids have proved unsatisfactory and $\left[{ }^{35} \mathrm{~S}\right]$ methionine labeling requires a lectin chromatography step to clearly distinguish its signal. $\left[{ }^{3} \mathrm{H}\right]$ Mannose was the most satisfactory label since our major interest was in labeling the proreceptor that carries only high-mannose chains.

The steady-state labeling experiments (6-24 h) confirm earlier studies that showed that corticosteroids increased the concentration of insulin receptors on IM-9 cells as measured 


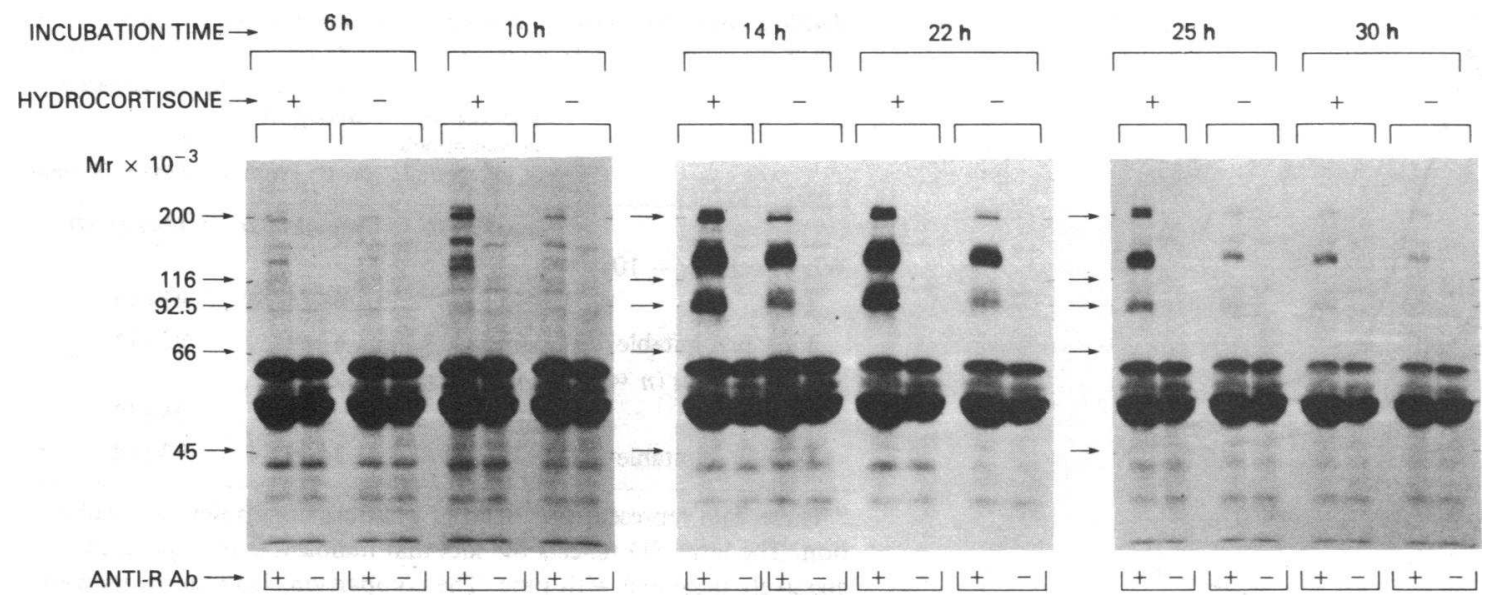

Figure 1. Steady-state labeling with $\left[{ }^{3} \mathrm{H}\right]$ mannose of insulin receptor precursor and mature subunits of cultured human lymphocytes (IM-9 line) incubated in the presence or absence of $1.4 \times 10^{-6} \mathrm{M}$ hydrocortisone. After a 6-h preincubation with or without hydrocortisone, the tracer was added and the incubation was pursued for 6-25 h. At each time point, a fraction of the cells was washed and solubilized in Triton X-100. The extract was immunoprecipitated with antiinsulin receptor antiserum. The immunoprecipitate was dissolved in SDS and dithiothreitol and run on SDS polyacrylamide (7.5\%) gel electrophoresis. The dried gels were autoradiographed on Kodak X-Omat

by equilibrium binding techniques (2) or by immunoprecipitation of surface-labeled receptors that uses antibodies to the insulin receptor (4). Taking advantage of the recently described precursor product relationship of the biosynthesis of the insulin receptor by Hedo et al. (6), the short-term pulse-chase experiments provide more direct evidence for the mechanism of steroid action. The insulin receptor is synthesized by way of a single chain precursor. This precursor has a molecular weight
AR film. The figure is a combination of two experiments: time-points $6,10,25$, and $30 \mathrm{~h}$ were studied on one occasion and time-points 14 and $22 \mathrm{~h}$ were studied in a separate experiment. Treatment with hydrocortisone is indicated by a " + " sign at the top of each lane. The "-" sign indicates treatment with the corticosteroid carrier alone (ethanol). Immunoprecipitation with antireceptor serum (Anti R-Ab) is indicated by the "+" sign at the foot of each lane. The "-" sign indicates incubation with normal control serum. Please note that labeling of the noninsulin receptor bands was not modified by the hydrocortisone treatment.

of 190,000 and is labeled at the earliest time point of the chase. Augmentation of the 190,000-mol wt precursor shows that the steroid effect is already seen at the earliest stage of the biosynthetic process that we have been able to study. This effect is then further transferred to subsequent processing steps to yield an increase in the mature subunits that are inserted into the plasma membrane.

The site of the regulatory step in receptor biosynthesis
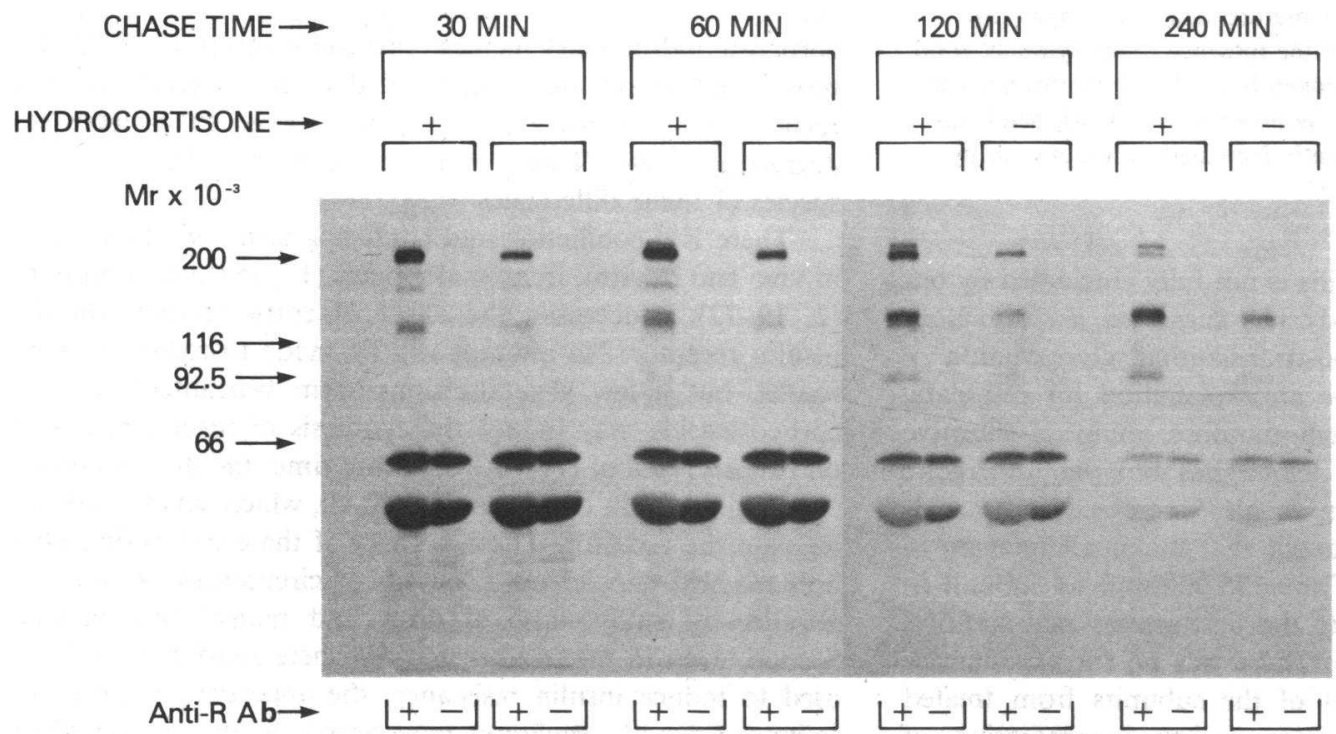

Figure 2. Pulse-chase labeling with $\left[{ }^{3} \mathrm{H}\right]$ mannose of insulin receptor precursor and subunits of cultured human lymphocytes (IM-9 line) incubated in the presence or absence of $1.4 \times 10^{-6} \mathrm{M}$ hydrocortisone. Cells preincubated for $6 \mathrm{~h}$ with or without hydrocortisone were pulse-labeled for 15 min in glucose-free medium containing $\left[{ }^{3} \mathrm{H}\right]$ mannose and subsequently chased in normal medium containing 2 mM unlabeled mannose. At each time point, a fraction of the cells was solubilized and the insulin receptor was immuno-

precipitated and analyzed by electrophoresis and autoradiography as described in the legend to Fig. 1. The figure represents a single experiment. Similar results were obtained using $\left[{ }^{3} \mathrm{H}\right]$ glucosamine as the tracer. Treatment with hydrocortisone is indicated by a " + " sign at the top of each lane. The "-" sign indicates treatment with the glucocorticoid carrier alone (ethanol). Immunoprecipitation with anti-receptor serum (Anti R$\mathrm{Ab}$ ) is indicated by the " + " sign at the foot of each lane. The "-" sign indicates incubation with normal control serum. A 170,000-M insulin receptor band not previously described is observed until $60 \mathrm{~min}$ of chase. This unknown insulin receptor component is also stimulated by hydrocortisone. Please note that labeling of the noninsulin receptor bands was not modified by the hydrocortisone treatment. 


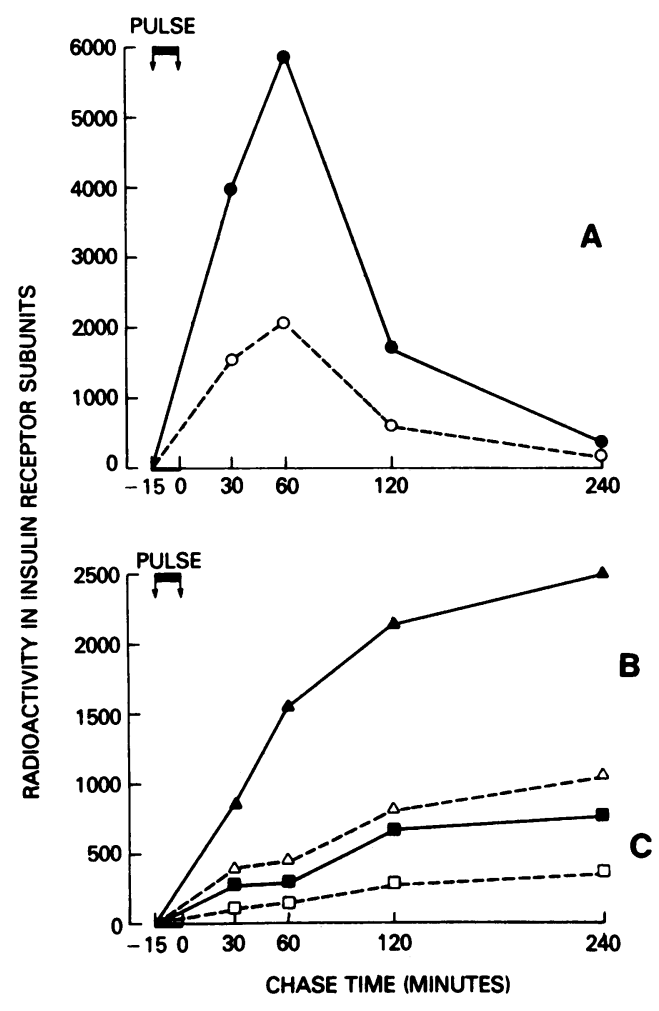

Figure 3. Kinetics of pulse-chase labeling with $\left[{ }^{3} \mathrm{H}\right]$ mannose of the insulin receptor precursor $(A, 190,000 \mathrm{~mol} \mathrm{wt})$ and the mature subunits $(B, 135,000 \mathrm{~mol} \mathrm{wt} ; C, 95,000 \mathrm{~mol} \mathrm{wt})$ of cultured human lymphocytes (IM-9 line) incubated in the presence or absence of 1.4 $\times 10^{-6} \mathrm{M}$ hydrocortisone. The data were obtained by excising the bands of interest from the gels represented on Fig. 2, eluting the slices in protosol, and counting the radioactivity in a scintillation counter. The results are expressed as specific counts per minute, the efficiency of the counter approaching 50\%. Top: Insulin receptor precursor, $190,000 M_{\mathrm{r}}$, in the presence (๑) or absence (0) of hydrocortisone. Bottom: Insulin receptor mature subunits, $135,000 M_{\mathrm{r}}$ (triangles) and 95,000 (squares), in the presence (plain symbols, solid line) or absence (open symbols, broken line) of hydrocortisone. The radioactivity incorporated into the nonspecific $60,000-M_{\mathrm{r}}$ band was also measured. It was not significantly increased in response to hydrocortisone ( $103 \pm 23 \%$ of control).

brought about by corticosteroids is not fully elucidated by our experiments. One recent study has suggested a stimulatory effect of steroids upon the posttranslational glycosylation of proteins (11). This cannot be an explanation for our data, since the labeling of the high-mannose, endo $\mathrm{H}$-sensitive precursor $(190,000 \mathrm{~mol} \mathrm{wt})$, which has not yet undergone posttranslational modification, is also increased in steroidtreated cells. Second, it is thought that the small increase in apparent molecular weight of the 135,000 -mol wt subunit in the course of a chase is due to the posttranslational addition of complex carbohydrates (7). There was no further increase in apparent molecular weight of the subunits from treated cells, despite a 2.5-fold increase in the incorporation of $\left[{ }^{3} \mathrm{H}\right]$ mannose. Third, previous studies have shown increases of the same magnitude by using surface labeling with the lactoperoxidase $/{ }^{125} \mathrm{I}$-Iodine technique instead of ${ }^{3} \mathrm{H}$-sugars (4). Since our data do not suggest that steroids are acting posttranslationally and since the effect is mediated presumably through the corticosteroid receptor, we speculate, but certainly do not
Table I. Radioactivity in Whole Cells and Soluble Extracts

\begin{tabular}{|c|c|c|c|}
\hline & \multirow{2}{*}{$\begin{array}{l}\text { Radioactivity } \\
\text { in control cells } \\
\times 10^{5} \mathrm{cpm} / \mathrm{ml}\end{array}$} & \multicolumn{2}{|c|}{$\begin{array}{l}\text { Radioactivity in hydrocortisone- } \\
\text { treated cells }\end{array}$} \\
\hline & & $\times 10^{5} \mathrm{cpm} / \mathrm{ml}$ & Percent of control \\
\hline & Mean $\pm 1 S D$ & Mean \pm 1 SD & Mean $\pm 1 S D$ \\
\hline \multicolumn{4}{|l|}{ Whole cells $(n=10)$} \\
\hline Total & $214 \pm 117^{*}$ & $208 \pm 136^{*}$ & $93 \pm 15$ \\
\hline TCA precipitable & $51 \pm 12$ & $47 \pm 14$ & $92 \pm 15$ \\
\hline \multicolumn{4}{|c|}{ Soluble extract $(n=7)$} \\
\hline Total & $211 \pm 127$ & $198 \pm 108$ & $96 \pm 17$ \\
\hline TCA precipitable & $38 \pm 16$ & $34 \pm 11$ & $93 \pm 14$ \\
\hline
\end{tabular}

* These data represent the mean of multiple time points of incubation. The large SD reflects the fact that radioactive incorporation progressively increased with time. The comparisons between experimental and control are, therefore, best expressed in percentage (right hand column).

prove, that the effect is very early, possibly at the level of gene transcription. For additional discussion, see reference 4.

It is unlikely that this effect is specific for the insulin receptor. Yet, there is a limited specificity. Corticosteroids do not increase the concentration of growth hormone receptors on IM-9 cells $(4,12)$; further, other unidentified glycoprotein bands seen on the gels are not augmented by steroid treatment (see Figs. 1 and 2, and the legend to Fig. 3).

In five independent studies using cultured cells, steroids have been shown to increase insulin receptor concentration. These include IM-9 cells $(2,4)$, U-937 monocytes (13), bladder carcinoma cells (14), rat hepatocytes (15), and 3T3-C2 mouse fibroblasts (16). Using the heavy isotope density shift technique, Salhanick et al. (15) showed that the corticosteroid-induced increase in insulin receptors on primary culture of rat hepatocytes was due to an increase in receptor synthesis. These results are fully consistent with our data. Using the same density shift method, Knutson et al. (16) demonstrated a corticosteroid-induced increase in insulin receptor of 3T3-C2 mouse fibroblasts, but concluded that the increase was not related to an increase synthesis but rather to a decreased degradation rate. These results suggest that there may be species or tissue differences.

There is a conflicting and confusing array of studies both in vivo and in vitro, in animal models $(17,18)$ and in humans (2, 19-22), concerning the effect of corticosteroids on the insulin receptor. No attempt will be made to reconcile these results, but a few generalizations seem warranted: In vivo corticosteroids may induce the synthesis of insulin receptors on certain types of cells. At the same time, the drug increases circulating insulin concentrations $(2,4)$, which acts to "down" regulate the receptor. The net effect of these competing phenomena will depend on a variety of circumstances, such as duration of study, dose of drug, and many other factors. Second, even in the in vitro setting where steroids have been used to induce insulin resistance, the apparent resistance to receptor "down" regulation may simply be due to the effect of the drug to stimulate receptor synthesis (23).

The major significance of the present study is to demonstrate a system in which the action of a drug or other agent can be tested for its ability to augment insulin receptor synthesis. Hydrocortisone represents the first agent that has been shown to stimulate the biosynthesis of the insulin proreceptor. 


\section{Acknowledgments}

The authors wish to thank Dr. Nathan Sharon for fruitful discussions regarding this study and Ms. Carol Culwell for her secretarial assistance.

\section{References}

1. Gavin, J. R., J. Roth, D. M. Neville, Jr., P. De Meyts, and D. N. Buell. 1974. Insulin-dependent regulation of insulin receptor concentration: a direct demonstration in cell culture. Proc. Natl. Acad. Sci. USA. 71:84-88.

2. Fantus, I. G., J. Ryan, N. Hizuka, and P. Gorden. 1981. The effect of glucocorticoids on the insulin receptor: an in vivo and in vitro study. J. Clin. Endocrinol. Metab. 52:953-960.

3. Rousseau, G. R., P. Cambron, and A. Amar-Costesec. 1980. Glucocorticoid receptor-mediated stimulation of 5'-nucleotidase in human lymphoblastoid IM-9 cells. FEBS (Fed. Eur. Biochem. Soc.) Lett. 121:249-252.

4. Fantus, I. G., G. A. Saviolakis, J. A. Hedo, and P. Gorden. 1982. Mechanism of glucocorticoid-induced increase in insulin receptors of cultured human lymphocytes. J. Biol. Chem. 257:8277-8283.

5. Jacobs, S., F. C. Kull, and P. Cuatrecasas. 1983. Monensin blocks the maturation of receptors for insulin and somatomedin $\mathrm{C}$ : identification of receptor precursors. Proc. Natl. Acad. Sci. USA. 80: 1228-1231.

6. Hedo, J. A., C. R. Kahn, M. Hayashi, K. M. Yamada, and M. Kasuga. 1983. Biosynthesis and glycosylation of the insulin receptor: evidence for a single polypeptide precursor of the two major subunits. J. Biol. Chem. 258:10020-10026.

7. Hedo, J. A., M. Kasuga, E. Van Obberghen, J. Roth, and C. R. Kahn. 1981. Direct demonstration of glycosylation of insulin receptor subunits by biosynthetic and external labeling: evidence for heterogeneity. Proc. Natl. Acad. Sci. USA. 78:4791-4795.

8. Kasuga, M., C. R. Kahn, J. A. Hedo, E. Van Obberghen, and K. M. Yamada. 1981. Insulin-induced receptor loss in cultured human lymphocytes is due to accelerated receptor degradation. Proc. Natl. Acad. Sci. USA. 78:6917-6921.

9. Laemmli, U. K. 1970. Cleavage of structural proteins during the assembly of the head of bacteriophage $\mathrm{T}_{4}$. Nature (Lond.). 227:680685.

10. Wheeler, R. H., K. L. Leach, A. C. La Forest, T. E. O'Toole, R. Wagner, and W. B. Pratt. 1981. Glucocorticoid receptor activation and inactivation in cultured human lymphocytes. J. Biol. Chem. 256: 434-441.

11. Bar-Shavit, Z., A. J. Kahn, L. E. Pegg, K. R. Stone, and S. L. Teitelbaum. 1984. Glucocorticoids modulate macrophage surface oli- gosaccharides and their bone binding activity. J. Clin. Invest. 73:12771283.

12. Knopf, R. F., B. A. Toretti, and P. A. Hosslet. 1978. Effect of hydrocortisone upon the insulin and growth hormone receptors of cultured human lymphocytes of the IM-9 line. Endocrine Society 60th Annual Meeting. Abstract 512. p. 331.

13. Robert, A., G. Grunberger, J.-L. Carpentier, J.-M. Dayer, L. Orci, and P. Gorden. 1984. The insulin receptor of a human monocytelike cell line: characterization and function. Endocrinology. 114:247253.

14. Sorimachi, K., Y. Yasumura, T. Kayuka, and T. Okayasu. 1983. Up-regulation of insulin receptors with dexamethasone in cultured human urinary bladder carcinoma cells. Endocrinol. Japon. 30:723729.

15. Salhanick, A. I., M. N. Krupp, and J. M. Amatruda. 1983. Dexamethasone stimulates insulin receptor synthesis in cultured rat hepatocytes. J. Biol. Chem. 258:14130-14135.

16. Knutson, V. P., G. V. Bonnet, and M. D. Lane. 1982. Control of insulin receptor level in 3T3 cells: effect of insulin-induced downregulation and dexamethasone-induced up-regulation on rate of receptor inactivation. Proc. Natl. Acad. Sci. USA. 79:2822-2826.

17. Olefsky, J. M., J. Johnson, F. Liu, P. Jen, and G. M. Reaven. 1975. The effects of acute and chronic dexamethasone administration on insulin binding to isolated rat hepatocytes and adipocytes. Metabolism. 24:517-527.

18. Grunfeld, C., K. L. Baird, E. Van Obberghen, and C. R. Kahn. 1981. Glucocorticoid-induced insulin resistance in vitro: evidence for both receptor and postreceptor defects. Endocrinology. 109:1723-1730.

19. Kahn, C. R., I. D. Goldfine, D. M. Neville, Jr., and P. De Meyts. 1978. Alterations in insulin binding induced by changes in vivo in the levels of glucocorticoids and growth hormone. Endocrinology. 103:1054-1066.

20. Cigolini, M., and U. Smith. 1979. Human adipose tissue in culture. VIII. Studies on the insulin-antagonistic effect of glucocorticoids. Metabolism. 28:502-510.

21. De Pirro, R., A. Bertoli, A. Fusco, I. Testa, A. V. Greco, and R. Lauro. 1980. Effect of dexamethasone and cortisone on insulin receptors in normal human male. J. Clin. Endocrinol. Metab. 51:503507.

22. Beck-Nielsen, H., R. De Pirro, and O. Pedersen. 1980. Prednisone increases the number of insulin receptors on monocytes from normal subjects. J. Clin. Endocrinol. Metab. 50:1-4.

23. Caro, J. F., and J. M. Amatruda. 1982. Glucocorticoid-induced insulin resistance. The importance of postbinding events in the regulation of insulin binding, action, and degradation in freshly isolated and primary cultures of rat hepatocytes. J. Clin. Invest. 69:866-875. 